\title{
Molecular iodine inhibits the expression of stemness markers on cancer stem-like cells of established cell lines derived from cervical cancer
}

\author{
Gabriele Davide Bigoni-Ordóñez ${ }^{1,2}$, Elizabeth Ortiz-Sánchez ${ }^{1}$, Pedro Rosendo-Chalma 1,3, \\ Heriberto A Valencia-González ${ }^{1,2}$, Carmen Aceves ${ }^{4^{*}}$ and Alejandro García-Carrancá ${ }^{1,5^{*}}$ (D)
}

\begin{abstract}
Background: Cancer stem cells (CSC) are characterized by deregulated self-renewal, tumorigenicity, metastatic potential, aberrant stemness signaling pathways, resistance to conventional therapy, and the ability to give rise to a progeny of proliferating cells that constitute the bulk of tumors. Targeting CSC will provide novel treatments for cancer. Different investigations have focused on developing complementary approaches that involve natural compounds that decrease chemo-resistance and reduce the side effects of conventional therapies. Since, it has been reported that molecular iodine $\left(I_{2}\right)$ exhibits antineoplastic effects and decreases tumor progression in some cancer models, we evaluated the potential effect of $\mathrm{I}_{2}$ on cell cultures enriched in cervical cancer stem-like cells.

Methods: HeLa and SiHa cervical cancer cells were treated with $200 \mathrm{uM} \mathrm{I} \mathrm{I}_{2}$ for $24 \mathrm{~h}$. After time, cells were cultured in CSC-conditioned medium (cervospheres) and viability assays were performed. Following, tumorigenic capabilities in cervospheres treated with $\mathrm{I}_{2}$ were evaluated in NOD/SCID mice. HeLa monolayer cells untreated and their respective cervosphere cells treated or untreated with $200 \mu \mathrm{M}$ of $\mathrm{I}_{2}$ for $24 \mathrm{~h}$ were xenotransplanted subcutaneously at different amounts and mice were monitored for at least 2 months.

Results: In the present study, monolayer and CSC-enriched cultures (cervospheres) from cervical cancer-derived cell lines, HeLa and $\mathrm{SiHa}$, showed that 200uM $\mathrm{I}_{2}$ supplementation inhibits proliferation of both and decreased their tumorigenic capacity, in vivo. This antineoplastic effect of $\mathrm{I}_{2}$ was accompanied by diminished expression of stemness markers including CD49f, CK17, OCT-4, NANOG, SOX2, and KLF4, as well as increased expression and activation of PPARY receptors.
\end{abstract}

Conclusions: All this data led us to suggest a clinical potential use of $\mathrm{I}_{2}$ for targeting CSC and improve current treatments against cervical cancer.

Keywords: Molecular iodine, Cervical cancer stem cells, Stemness markers, PPAR gamma

\footnotetext{
*Correspondence: caracev@unam.mx; carranca@biomedicas.unam.mx

${ }^{4}$ Instituto de Neurobiología, Universidad Nacional Autónoma de México,

Boulevard Juriquilla 3001, Juriquilla. Campus-Juriquilla., Querétaro 76230, Qro,

Mexico

'División de Investigación Básica, Laboratory of Virus and Cancer, Instituto

Nacional de Cancerología, Secretaria de Salud, Av. San Fernando No. 22,

Sección XVI, Tlalpan, 14080 Ciudad de México, CP, Mexico

Full list of author information is available at the end of the article
}

(c) The Author(s). 2018 Open Access This article is distributed under the terms of the Creative Commons Attribution 4.0 International License (http://creativecommons.org/licenses/by/4.0/), which permits unrestricted use, distribution, and reproduction in any medium, provided you give appropriate credit to the original author(s) and the source, provide a link to the Creative Commons license, and indicate if changes were made. The Creative Commons Public Domain Dedication waiver (http://creativecommons.org/publicdomain/zero/1.0/) applies to the data made available in this article, unless otherwise stated. 


\section{Background}

In 2012, cancer caused 8.2 million deaths with 14.1 million new cases with a higher prevalence in men than in women. Cervical cancer is the 4th most common cancer in women with an estimated of 528,000 new cases in 2012 and 266,000 deaths. According to the data, the mortality in Mexico for cancer in 2012 was 40,053, with cervical cancer responsible for $11.9 \%$ of those deaths [1].

High-risk human papillomaviruses (HPV) are related for the development of cervical cancer [2]. This is achieved through the persistent infection of HPV until later integrates his viral DNA into the host cell. The oncogenic potential of HPV resides in their oncoproteins E6 and E7 that disrupt the cell cycle control. The E6 function of high-risk HPV types is the binding and targeting of p53 for degradation and the function of E7 is binding the retinoblastoma tumor suppressor protein $(\mathrm{pRb})$ for degradation allowing the release of the transcription factor (EF2) that promotes the expression of numerous genes that control DNA synthesis and cell proliferation $[3,4]$.

Tumors exhibit a high degree of cellular heterogeneity, and we now believe that only certain cells, known as cancer stem cells (CSC), have the ability to maintain the growth of the tumor mass and the capacity to invade other tissues. The proportion of CSC is variable depending on tumor type and stage $[5,6]$. CSCs are undifferentiated cells that have the capacity for self-renewal, chemo-radiation resistance, promoting metastasis and cancer recurrence [7-9]. The presence of CSC has been shown in several types of cancers, such as breast, colon, brain and many others, as identified using the expression of various markers [10-14]. The presence of cervical cancer stem cells (CCSC) has been determined through the expression of CD49f and cytokeratin 17 (CK17) $[15,16]$.

CD49f, also known as alpha 6 integrin, belongs to the alpha family of integrins and is found on the cell membrane. CD49f has been used as an epithelial stem marker in the human epidermis [17], as an important marker for enrichment of cancer stem cells [18], and described as a target during HPV binding to initiate an intracellular signaling cascade for virus entry [19]. Cytokeratins are proteins that are part of epithelial cells, and their expression depends on the degree of differentiation they acquire. Keratin expression in cervical tissue has been well defined, and it was observed that sub-columnar reserve cells, where the stem cell population of the uterine cervix is found, showed specific expression of CK17 [20]. Identification and characterization of cancer stem cell-like cells from primary carcinomas of the cervix uteri found expression of CK17 [21], suggesting that cells expressing this cytokeratin also as a target of HPV [22]. Our group has previously shown expression of CD49f and CK17 as possible markers for CCSC and that sphere cultures (cervospheres) are enriched in CCSC showing high tumorigenic in vivo assays compared to their counterparts grown as monolayers $[15,16]$.

Self-renewal and pluripotency are maintained by the expression of Oct4, Sox2, Klf4, and Nanog on embryonic stem (ES) cells [23-26]. There is evidence that these stemness genes are relevant for tumor transformation, metastasis, and tumorigenicity in human malignancies [27-29]. In clinical terms, chemo and radio-therapy are the gold standard for the treatment of cervical cancer in advanced stages. Depending on the stage of the tumor, the rate of recurrent disease and inefficient treatments could be due to the presence of drug-resistant CSC. For these reasons, different investigations have focused on developing complementary approaches that involve natural compounds that decrease chemo-resistance and reduce the toxic effects of conventional therapies. $\mathrm{I}_{2}$ exerts significant antineoplastic effects on several types of cancer and multiple mechanisms could mediate its actions. Among these, $\mathrm{I}_{2}$ can react with arachidonic acid generating the iodolipid called 6-iodolactone (6-IL), which has been confirmed to be an agonist of the peroxisome proliferator-activated receptor type gamma (PPAR $\gamma)$. The activation of these receptors decreases the expression of specific markers associated with invasiveness and epithelial-mesenchymal transition [30-34]. Previous studies from our laboratory showed that $\mathrm{I}_{2}$ impairs chemo-resistance mechanisms, enhances doxorubicin retention and induces downregulation of chemo-resistance markers p21, Bcl-2 and MDR-1 in chemo-resistant MCF-7 cells [35]. In the present work, we showed that in cultures growing as monolayers or cervospheres of $\mathrm{HeLa}$ and $\mathrm{SiHa}$ cell lines derived from cervical cancer, $\mathrm{I}_{2}$ was able to inhibit proliferation and the ability to form tumors in mice. This effect includes a decrease in expression of CD49f and CK17 putative stem cell markers and stem transcription factors OCT-4, SOX2, KLF4, NANOG. We propose that in this model, the action of $\mathrm{I}_{2}$ could be through the activation of the PPAR gamma receptors.

\section{Methods}

\section{Cell culture and $\mathrm{I}_{2}$}

Human CC cell lines, HeLa (ATCC@-CRM-CCL-2 T, adenocarcinoma, HPV-18) and SiHa (ATCC@-HTB-35, squamous cell carcinoma, HPV-16), were obtained from ATCC (American Type Culture Collection, Manassas, VA, USA). Monolayer culture cells were seeded (500,000 cells) in $100 \mathrm{~mm}$ cell culture dishes (Corning, Inc., Corning, NY, USA) in $7 \mathrm{~mL}$ of medium, grown at $37{ }^{\circ} \mathrm{C}$ in a humidified atmosphere with 5\% CO2 in DMEM media $\left(\mathrm{Gibco}^{\circ}\right)$ supplemented with $10 \%$ fetal bovine serum $\left(\mathrm{Gibco}^{\oplus}\right)$ and $100 \mathrm{U} / \mathrm{mL}$ penicillin/streptomycin (Invitrogen, Carlsbad, CA, USA) Molecular iodine was 
prepared with $13 \mathrm{~g}$ of crystalline iodine (Macron-Avantor, Center Valley, PA, USA) and $60 \mathrm{~g}$ of potassium iodide (Sigma-Aldrich, St. Louis, MO, USA) in one liter of $\mathrm{dd}_{2} \mathrm{O}$. The iodine concentration was confirmed by titration with a solution of $0.1 \mathrm{~N}$ sodium thiosulfate. The use of all cell lines and cell cultures were approved by Research and Bioethics Committees of Instituto Nacional de Cancerología [Prot. No. 018/012/IBI) (CEI/1096/17), Dated 03.02.2018].

\section{Cervospheres}

For the formation of cervospheres derived from CC cell lines, monolayer cell cultures were grown to $70-80 \%$ confluence and then harvested, counted, and washed with Phosphate buffer solution (PBS) to remove the remainder of FBS. After that, cells were cultured in DMEM F12 media $\left(\right.$ Gibco $\left.^{\circ}\right)$ supplemented with $20 \mathrm{ng} / \mathrm{mL}$ epidermal growth factor (BioLegend Inc., San Diego, CA, USA), $20 \mathrm{ng} / \mathrm{mL}$ basic fibroblast growth factor (BioLegend Inc., San Diego, CA, USA), $10 \mu \mathrm{l} / \mathrm{mL}$ B27 (50X, Gibco ${ }^{\circ}$ ) and $100 \mathrm{U} / \mathrm{mL}$ penicillin/ streptomycin (Invitrogen, Carlsbad, CA, USA) at a density of $3 \times 10^{3}$ cells $/ \mathrm{ml}$ in $100 \mathrm{~mm}$ ultra-low adherence dishes of (Corning, Inc., Corning, NY, USA). Cells were grown at $37{ }^{\circ} \mathrm{C}$ in a humidified atmosphere with $5 \%$ CO2 for 3 days and cervosphere formation was monitored daily.

\section{Molecular iodine treatments}

The $\mathrm{I}_{2}$ was previously diluted in culture medium and then added to the cells. The monolayers and spheres cultures of $\mathrm{SiHa}$ and HeLa cell lines were treated at a concentration of $200 \mu \mathrm{M}$ of $\mathrm{I}_{2}$ for $24 \mathrm{~h}$. After time, cultures were collected and processed for the corresponding tests.

\section{Analysis of markers by flow cytometry}

Monolayers and cervospheres treated or untreated with $200 \mu \mathrm{M}$ of $\mathrm{I}_{2}$ for $24 \mathrm{~h}$ were collected separately and placed in a tube where they were allowed to remain for $15 \mathrm{~min}$. After that time, supernatant was removed and the bottom cells were washed with PBS and spun down at $500 \mathrm{~g}(r=11 \mathrm{~cm})$ for $5 \mathrm{~min}$ at room temperature. Supernatant was removed and cells were resuspended in flow buffer (PBS 1X, 0.05\% BSA) and disaggregated by mechanic pipetting. Before incubation with anti-CK17, anti-OCT-4, anti-SOX2, anti-NANOG, and anti-KLF4 antibodies, cells were permeabilized by incubation with methanol for $15 \mathrm{~min}$ on ice. Then, cells were washed and incubated with primary antibody. For each primary antibody, $5 \times 10^{5}$ cells were incubated with anti-CD49f-PE (BD Bioscience, CA, USA), anti-CK17 (Santa Cruz Biotechnology, Inc., Dallas, TX, USA), anti-OCT4-AlexaFluor488, anti-SOX2-AlexaFluor488 (both BioLegend Inc., San Diego, CA, USA), anti-NANOG-PE (BD
Bioscience, CA, USA), anti-KLF4-APC (R\&D Systems, Inc., Minneapolis, MN, USA) for 30 min on ice. After that time, cells were washed with $300 \mu \mathrm{L}$ of flow buffer and spun down at $500 \mathrm{~g}(r=11 \mathrm{~cm})$ for $5 \mathrm{~min}$ at room temperature. Cells incubated for anti-CK17, after the time elapsed, were washed and incubated with FITC-coupled secondary antibody for $30 \mathrm{~min}$ on ice. At the end of the incubation, cells were washed again with flow buffer, spun down, and supernatant was removed. All cells were then washed and fixed with $4 \% \mathrm{p}$-formaldehyde in PBS. Every marker was also incubated with isotype controls under the same conditions of the primary antibodies. Stained cells were read in ATTUNE NXT (Thermo Fisher Scientific Inc). At least ten thousand events were recorded for each flow cytometry measurement. Flow $\mathrm{Jo}^{\circ}$ software was utilized for analyzing data.

\section{Western blot analysis}

The total proteins from HeLa monolayers (confluence 70-80\%) and cervospheres treated or untreated with $200 \mu \mathrm{M}$ of $\mathrm{I}_{2}$ for $24 \mathrm{~h}$ were extracted with RIPA buffer (150 mM NaCl, 1\% Nonidet P-40, 0.5\% deoxycholate, $0.1 \%$ sodium dodecyl sulfate [SDS], and $50 \mathrm{mM}$ Tris$\mathrm{HCl}, \mathrm{pH}$ 8.0) supplemented with a complete EDTA-free protease inhibitor cocktail (Roche, USA) and incubated on ice for $20 \mathrm{~min}$. The protein concentrations were measured using the Bradford method (Bio-Rad, USA). Samples containing $70 \mathrm{mg}$ of protein were boiled in SDS containing sample buffer (10\% SDS, $20 \%$ glycerol, $20 \mathrm{mM}$ Tris-Cl, $\mathrm{pH}$ 6.8, $10 \mathrm{mM} \beta$-mercapto-ethanol, and $0.05 \%$ bromophenol blue), separated by SDS polyacrylamide gel electrophoresis (SDS-PAGE) and transferred onto nitrocellulose membranes. The membranes were blocked with 5\% nonfat milk in PBS containing $0.1 \%$ Tween-20 for $1 \mathrm{~h}$ and incubated with the appropriate antibody dilution. The PPAR $\gamma$ antibody (sc-7196, Santa Cruz Biotechnology, Inc., Dallas, TX, USA) was used at a dilution of 1:1000 and GAPDH antibody (sc-48167, Santa Cruz Biotechnology, Inc., Dallas, TX, USA) was used at a dilution of 1:10000. The following HRP-conjugated secondary antibodies were used at a dilution of 1:10000 anti-rabbit (sc-2313, Santa Cruz Biotechnology, Inc., Dallas, TX, USA) and the anti-goat (sc-2020, Santa Cruz Biotechnology, Inc., Dallas, TX, USA) was used at a dilution of 1:20000. The proteins were visualized through an enhanced chemiluminescence reaction using the Super Signals West Pico Chemiluminescent Substrate (Thermo Fisher Scientific Inc., Pierce Protein Research Products, Rockford, IL, USA). Densitometry was performed using ImageJ software (version 1.41, National Institutes of Health, Bethesda, MD, USA) and chemiluminescence was normalized to the level of GAPDH protein. 
Total RNA extraction, quantification of mRNA by real-time quantitative PCR (RT-qPCR)

RNA extraction of HeLa monolayers (confluence 70-80\%) and cervospheres treated or untreated with $200 \mu \mathrm{M}$ of $\mathrm{I}_{2}$ for $24 \mathrm{~h}$ was carried out using Trizol (Invitrogen, Cat. No. 15596026), the extracted RNA was treated with DNaseI (ThermoFisher, Cat. No. EN0521) and purified using the Direct-zol ${ }^{\text {mu }}$ kit, RNA MicroPrep (Zymo Research, Cat. No. R2060). The purified RNA was quantified using an Epoch ${ }^{\text {tw }}$ spectrophotometry system and subjected to retrotranscription with $2000 \mathrm{ng}$ of RNA with the SuperScript ${ }^{\mathrm{m} x}$ IV First-Strand Synthesis System (Invitrogen, Cat. No. 18091050) to obtain cDNA. By means of real-time PCR, the cDNA was be evaluated to determine the expression levels of the PPARY (F-PPARy: TCT CTC CGT AAT GGA AGA CC and R-PPARy: GCA TTA TGA GAC ATC CCC AC), PTEN (F-PTEN: GAT GAG GCA TTA TCC TGT ACA CA and R-PTEN: CTC TTC AGA TAC TCT TGT GCT GT) E6 (F-E6: GCG ACC CTA CAA GCT ACC TG and R-E6: GTT GGA GTC GTT CCT GTC GT) and E7 (F-E7: TGA AAT TCC GGT TGA CCT TC and R-E7: CAC GGA CAC ACA AAG GAC AG) genes. The oligonucleotides for the GAPDH gene (F-GAPDH: AAG GTC GGA GTC AAC GGA TTT G and R-GAPDH: CCA TGG GTG GAA TCA TAT TGG AA) were used as control. Placing $100 \mathrm{ng}$ of $\mathrm{cDNA}, 12.5 \mu \mathrm{L}$ of the master mix Maxima SYBR and $10 \mathrm{pmol}$ of each oligonucleotide in a total volume of $25 \mu \mathrm{L}$ carries out real-time PCR. The reaction conditions are $95{ }^{\circ} \mathrm{C}$ for $10 \mathrm{~min}$ for initial denaturation, 40 cycles of $95{ }^{\circ} \mathrm{C}$ for $15 \mathrm{~s}, 60{ }^{\circ} \mathrm{C}$ for $30 \mathrm{~s}$ and $72{ }^{\circ} \mathrm{C}$ for $30 \mathrm{~s}$ for denaturation, alignment and extension, respectively. The reaction was performed on the QIAGEN Rotor-Gene Q equipment. The expression levels of the mRNAs were determined from the threshold cycle $(\mathrm{Ct})$, and the relative expression levels were calculated using the $2^{-\Delta \Delta C t}$ method. For mRNA quantification, the $\mathrm{Ct}$ values were normalized to the expression of the GAPDH mRNA level.

\section{Viability assay}

The effects in viability of HeLa and $\mathrm{SiHa}$ monolayers treated or untreated with 100,200 and $400 \mu \mathrm{M}$ of $\mathrm{I}_{2}$ for $24 \mathrm{~h}$ and HeLa cervospheres treated or untreated with $200 \mu \mathrm{M}$ of $\mathrm{I}_{2}$ for $24 \mathrm{~h}$, were analyzed using the OZBlue Cell Viability Kit (OZ Biosciences, San Diego, USA) following the supplier's instructions.

\section{Animals and in vivo tumorigenic assays}

This study was approved by Research and Bioethics of Instituto Nacional de Cancerología's Committee [Prot. No. 018/012/IBI) (CEI/1096/17), Dated 03.02.2018]. NOD/SCID (Non-Obese Diabetic/Severe Combined Immunodeficiency) female mice were used in this work to test the tumorigenic capacity of CCSC-like $\mathrm{I}_{2}$-treated and untreated. The animals were 4-6 weeks old, weighed $21-25 \mathrm{~g}$ and were obtained from the Unidad de Modelos Biológicos of the Instituto de Investigaciones Biomédicas, UNAM. After acclimation in the bioterium of Instituto Nacional de Cancerología, they were randomly designated to experimental groups. Mice were xenotransplanted subcutaneously (s.c) with HeLa monolayer cells and their respective cervosphere cells treated or untreated with $200 \mu \mathrm{M}$ of $\mathrm{I}_{2}$ for $24 \mathrm{~h}$ at different amounts using six mice per group. Throughout experiment, mice lived in a room with $12-\mathrm{h} / 12-\mathrm{h}$ light/dark cycle, at a temperature of $27{ }^{\circ} \mathrm{C}, 60 \%$ of relative humidity and had free access to chow and water. Mice were monitored for at least 2 months. The handling and execution of experimental procedures in mice were carried out according with local and international guidelines such as the official Mexican standard NOM-062-ZOO-1999 (Technical specifications for the production, care and use of laboratory animals), the code of ethics of IIB-UNAM and other international guidelines. For subcutaneous tumors in mice, the maximal allowable size is $2 \mathrm{~cm}$ in diameter (Tumor Policy for Mice and Rats from Boston University Research Compliance). Tumor growth was monitored three times a week for up to 8 weeks. At the end of the 8 weeks, a humanitarian final point was made; the mice were euthanized in a compressed $\mathrm{CO}_{2}$ chamber. After that, tumors were extracted through a cut made in the skin and they were measured, weighed and photo-documented. Each tumor was measured by a vernier caliper and the tumor volume was calculated using the Attia-Weiss formula "Tumor volume $=(0.4)(a)\left(b^{\wedge} 2\right)$ ", where "a" is the largest diameter and " $\mathrm{b}$ " the smallest diameter of each tumor.

\section{Statistical analysis}

The data were analyzed using GraphPad Prism software (v 6.0; GraphPad Software, Inc., CA, USA). One or two-way ANOVA was performed to determine the significance of differences between groups. Data are expressed as mean \pm standard deviation (SD), and values with $P<0.05$ were considered statistically significant.

\section{Results}

Molecular iodine interferes with viability of HeLa and $\mathrm{SiHa}$ monolayer cell cultures and cervosphere formation of HeLa

A dose-response curve $(100 \mu \mathrm{M}, 200 \mu \mathrm{M}, 400 \mu \mathrm{M})$ of $\mathrm{I}_{2}$ for $24 \mathrm{~h}$ was carried out to evaluate cell viability under adherent (monolayer) culture conditions of HeLa and $\mathrm{SiHa}$ cells (Fig. 1a). HeLa cells were slightly more resistant than $\mathrm{SiHa}$ at $100 \mathrm{uM} \mathrm{I} \mathrm{I}_{2}$ and the antiproliferative effect of $\mathrm{I}_{2}$ exhibited a sustained dose-response in both cells types. To evaluate a possible effect of $\mathrm{I}_{2}$ in CCSC-like cells, since $400 \mu \mathrm{M} \mathrm{I}_{2}$ showed high cytotoxicity, we selected $200 \mu \mathrm{M} \mathrm{I}_{2}$ for further experiments. A supplement 


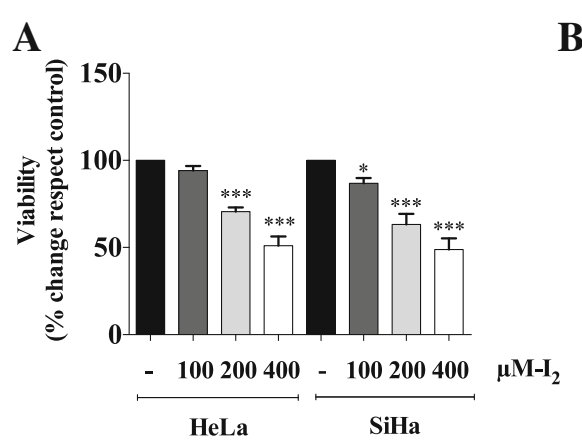

\section{B}

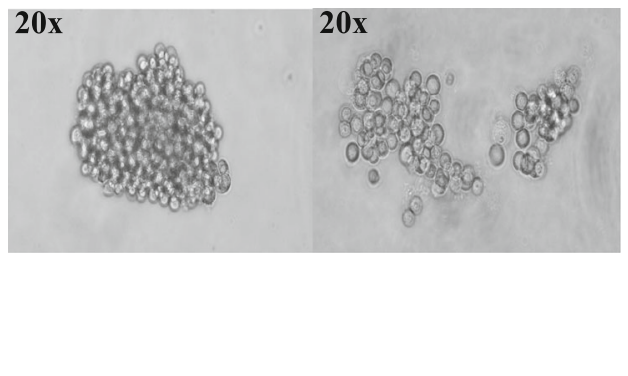

C

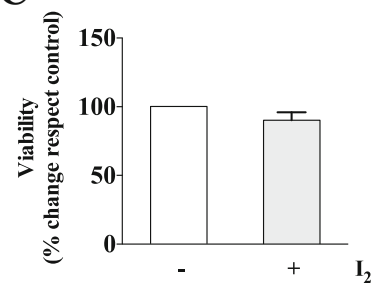

Fig. 1 Effect of $\mathrm{I}_{2}$ on HeLa and SiHa cells and inhibition of HeLa cervosphere formation. (a) Viability assay of monolayer cultures of HeLa and SiHa cells treated with 100, 200 and $400 \mu \mathrm{M}\left(\mathrm{I}_{2}\right)$ and deionized water (control) for $24 \mathrm{~h}$. (b). HeLa cervospheres without treatment (left) and treated with $200 \mu \mathrm{M}\left(\mathrm{I}_{2}\right)$ for $24 \mathrm{~h}$ (right) (c). HeLa cervosphere viability assay without treatment and treated with $200 \mu \mathrm{M}\left(\mathrm{I}_{2}\right)$ for $24 \mathrm{~h}$. Data are expressed as mean $\pm \mathrm{SD}\left(n=3\right.$ independent assays), and the asterisk indicates a significant difference with respect to the control $\left({ }^{*} P<0.05,{ }^{* * *} P<0.001\right)$

of $200 \mathrm{uM} \mathrm{I}_{2}(24 \mathrm{~h})$ interfered with HeLa cervosphere formation, since the $\mathrm{I}_{2}$-treated cervospheres were observed to be smaller, with irregular conformation compared to the untreated cervospheres (Fig. 1b), however, cell viability wasn't affected (Fig. 1c).

\section{CD49f expression in HeLa cervospheres and SiHa monolayer and cervosphere cultures is inhibited by molecular iodine}

CD49f protein was evaluated under non-adherent conditions (cervospheres) for 7 days (data not shown). On the third day, we found the highest protein level of CD49f suggesting a significant proportion of cancer stem cell-like cells. Monolayer and cervospheres were treated on the second day with $200 \mu \mathrm{M} \mathrm{I} \mathrm{I}_{2}$ or deionized water (control) for $24 \mathrm{~h} . \mathrm{I}_{2}$ was effective in reducing the expression of CD49f in HeLa and $\mathrm{SiHa}$ cervospheres and their respective monolayers, even the expression of CD49f in HeLa monolayer is very low, treatments with molecular iodine decreased its expression, although not to significant levels under these treatment conditions (Fig. 2).

Molecular iodine significantly reduces CK17 in both HeLa and $\mathrm{SiHa}$ monolayer and cervosphere cultures

CK17 is a marker for cervical stem cell identification $[16,21]$ and is an essential marker for the identification of CCSC. As with the CD49f molecular iodine assay, HeLa and $\mathrm{SiHa}$ cervospheres and monolayer cells were treated on the second day with $200 \mu \mathrm{M}$ of $\mathrm{I}_{2}$ or deionized water (control) for $24 \mathrm{~h}$. Cytometry analysis showed that $\mathrm{I}_{2}$ was capable of decreasing CK17 protein levels in both HeLa and SiHa cells under monolayer and cervosphere conditions (Fig. 3).

\section{OCT-4, SOX2, KLF4 and NANOG stemness markers are} significantly reduced by molecular iodine treatment only in HeLa and SiHa cervospheres

Identifying stemness markers such as OCT-4, SOX2, KLF4, and NANOG is needed to evaluate stemness of our cervospheres. We evaluated these transcription factors in HeLa and $\mathrm{SiHa}$ cells grown as monolayers and cervospheres in the presence or absence of $\mathrm{I}_{2}$ treatment. As expected, we found more stemness marker proteins in cervospheres compared to monolayer cells. Interestingly, OCT-4, SOX2, KLF4, and NANOG markers were down regulated by $\mathrm{I}_{2}$ treatments in both cervosphere and monolayer cultures of $\mathrm{HeLa}$ (Fig. 4) and $\mathrm{SiHa}$ (Fig. 5) cells.

\section{Activation of PPAR gamma is up-regulated by molecular} iodine treatments in HeLa cells

It has been proposed that the antineoplastic effect of the molecular iodine is mediated by activation of PPARY receptors by 6 -iodolactone, in turn causing an increase in these receptors after treatment $[33,34]$. Monolayer and cervospheres of HeLa cells were incubated with $200 \mu \mathrm{M}$ of $\mathrm{I}_{2}$ for $24 \mathrm{~h}$, resulting in a significant increase in PPAR gamma proteins compared to their untreated counterparts (Fig. 6a, b). To corroborate the activation of PPAR $\gamma$ we 

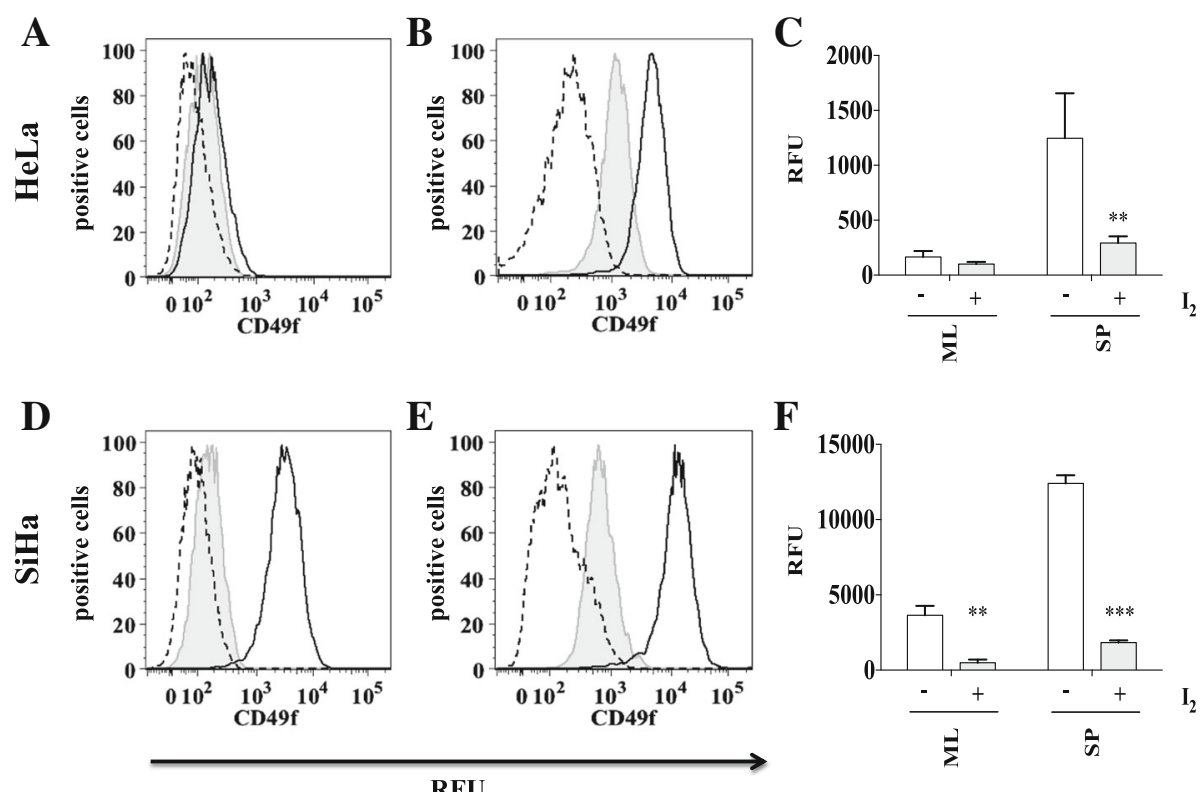

Fig. 2 CD49f is reduced by $\mathrm{I}_{2}$ treatment in HeLa and SiHa monolayers and spheres cells. Monolayer cultures of HeLa and SiHa cells were treated with $200 \mu \mathrm{M}\left(\mathrm{I}_{2}\right)$ for $24 \mathrm{~h}$ (tinted with line), without treatment (black line), isotype (long dashes) (a and $\mathbf{d}$ ). Sphere cultures of HeLa and SiHa cells were treated with $200 \mu \mathrm{M}$ of $\left(\mathrm{I}_{2}\right)$ for $24 \mathrm{~h}$ (tinted grey with line), without treatment (black line), isotype (long dashes) (b and e). CD49f was analyzed by flow cytometry. ( $\mathbf{a}, \mathbf{b}, \mathbf{d}, \mathbf{e})$. Data are expressed as mean \pm SD $(n=3$ independent assays), and the asterisk indicates a significant difference with respect to the control $\left.{ }^{* *} P<0.01,{ }^{* *} P<0.001\right)$ ( $(\mathbf{c}$ and $\mathbf{f}$ )
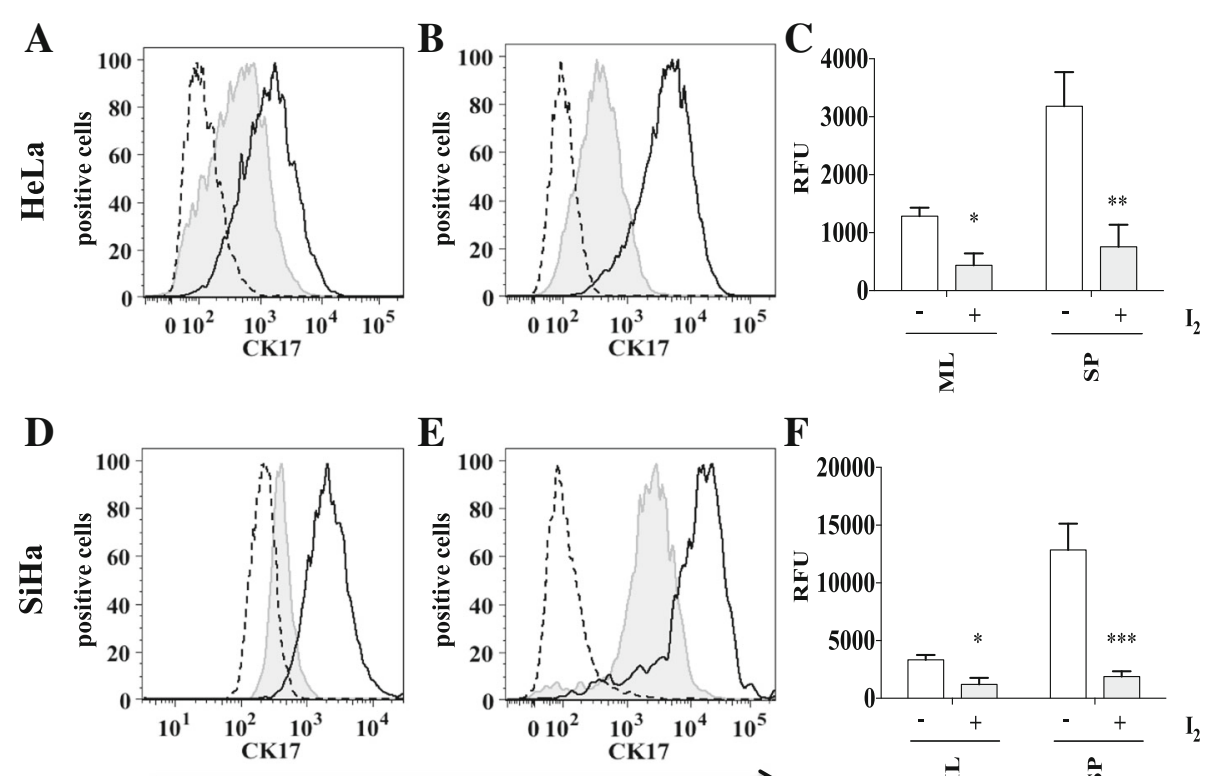

$\mathbf{E}$

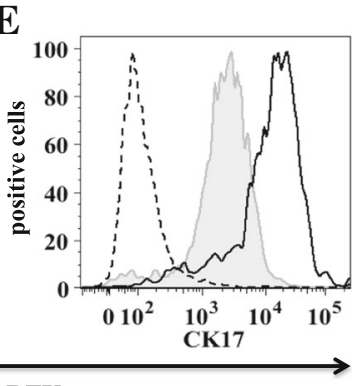

$\mathbf{F}$

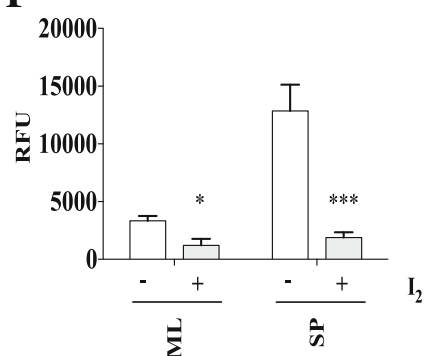

Fig. $3 \mathrm{CK} 17$ is reduced by $\mathrm{I}_{2}$ treatment in HeLa and SiHa monolayers and spheres cells. Monolayer cultures of HeLa and SiHa cells were treated with $200 \mu \mathrm{M}\left(\mathrm{I}_{2}\right)$ for $24 \mathrm{~h}$ (tinted grey with line), without treatment (black line), isotype (long dashes) (a and $\left.\mathbf{d}\right)$. Sphere cultures of HeLa and SiHa cells were treated with $200 \mu \mathrm{M}\left(\mathrm{I}_{2}\right)$ for $24 \mathrm{~h}$ (tinted grey with line), without treatment (black line), isotype (long dashes) (b and e). CK17 was analyzed by flow cytometry. ( $\mathbf{a}, \mathbf{b}, \mathbf{d}, \mathbf{e})$. Data are expressed as mean $\pm S D(n=3$ independent assays), and the asterisk indicates a significant difference with respect to the control $\left({ }^{*} P<0.05,{ }^{* *} P<0.01,{ }^{* * *} P<0.001\right)$ (c and $\mathbf{f}$ ) 

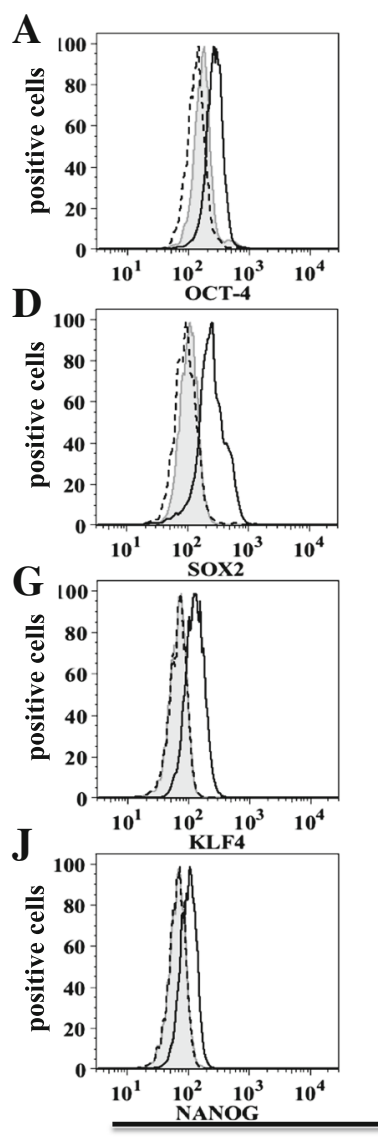

B

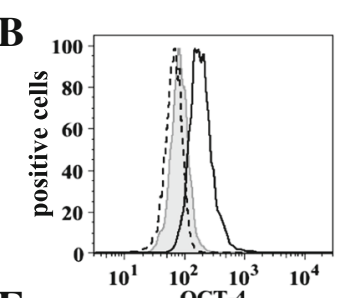

$\mathbf{E}$

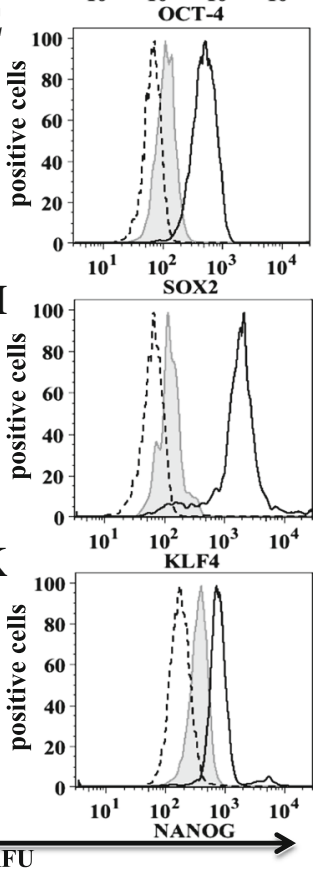

C
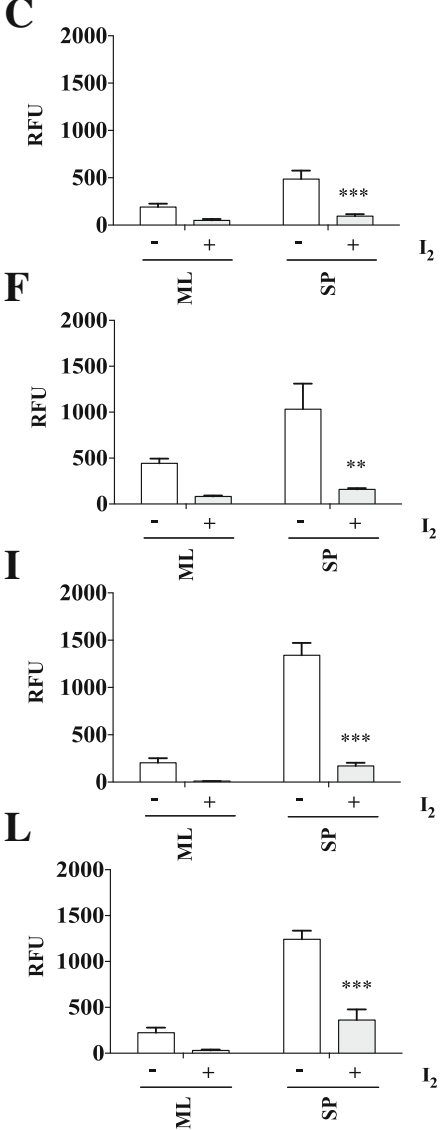

Fig. $4 I_{2}$ treatment significantly reduces OCT-4, SOX2, KLF4 and NANOG in HeLa cells grown as spheres. Monolayer cultures of HeLa cells were treated with $200 \mu \mathrm{M}\left(\mathrm{I}_{2}\right)$ for $24 \mathrm{~h}$ (tinted grey with line), without treatment (black line), isotype (long dashes) (a, $\mathbf{d}, \mathbf{g}$, j). Sphere cultures of HeLa cells were treated with $200 \mu \mathrm{M}\left(\mathrm{I}_{2}\right)$ for $24 \mathrm{~h}$ (tinted grey with line), without treatment (black line), isotype (long dashes) (b, e, h, k). Markers were analyzed by flow cytometry. ( $\mathbf{a}, \mathbf{b}, \mathbf{d}, \mathbf{e}, \mathbf{g}, \mathbf{h}, \mathbf{j}, \mathbf{k})$. Data are expressed as mean \pm SD ( $n=3$ independent assays), and the asterisk indicates a significant difference with respect to the control $\left({ }^{* *} P<0.01,{ }^{* * *} P<0.001\right)(\mathbf{c}, \mathbf{f}, \mathbf{i}, \mathbf{I})$

analyzed the expression of PTEN (phosphatase and tensin homolog deleted on chromosome ten), a known PPAR $\gamma$-regulated gene (reviewed in [36]). Figure 6c shows that $\mathrm{I}_{2}$-supplemented HeLa cells exhibit significant increase of PTEN gene expression in both monolayers and cervospheres. This result indicates that the mechanism of the antineoplastic effects of molecular iodine could be through PPAR gamma. Figure 6d, e shows the effect of $\mathrm{I}_{2}$ on HPV18 E6 and E7 gene expression, resulting in a significant reduction of $E 6$ and $E 7$ expression in monolayers cells and no effect in cervospheres treated with $\mathrm{I}_{2}$.

\section{Molecular iodine treatments decrease the capacity for tumor formation of HeLa cervospheres}

It has been demonstrated that cervospheres have higher tumorigenic capacity compared to their monolayer counterparts $(15,16)$. In this paper, we evaluated the effect of $\mathrm{I}_{2}$ treatments on cervosphere tumorigenic capacity using an in vivo assay. Mice were inoculated with HeLa cervospheres pre-incubated for $24 \mathrm{~h}$ with $200 \mu \mathrm{M} \mathrm{I}_{2}$ or deionized water. Each animal was inoculated with both populations on the left or right side, respectively (Fig. 7a).

Figure $7 \mathrm{~b}, \mathrm{c}$ show that $\mathrm{I}_{2}$-treated cervospheres promoted smaller tumors in $6 / 6$ mice, suggesting an anti-tumorigenic effect of $\mathrm{I}_{2}$ on these cervical cancer highly tumorigenic cells, as characterized by CD49f, CK17 and stemness markers. Tumors began to grow from 17 days after inoculation in the mice and tumor growth was evaluated for 49 days. We observed that untreated cervospheres formed bigger tumors with a maximum average size of $594.9 \mathrm{~mm}^{3}$ whereas the cervospheres treated with $\mathrm{I}_{2}$ formed tumors of much smaller size, with a maximum average size of $150.8 \mathrm{~mm}^{3}$ (Fig. 7d). No adverse events were found in the experimental groups.

\section{Discussion}

The percentage of cancer stem cells is very low in tumors, which makes it difficult to study them. Spheroidal 

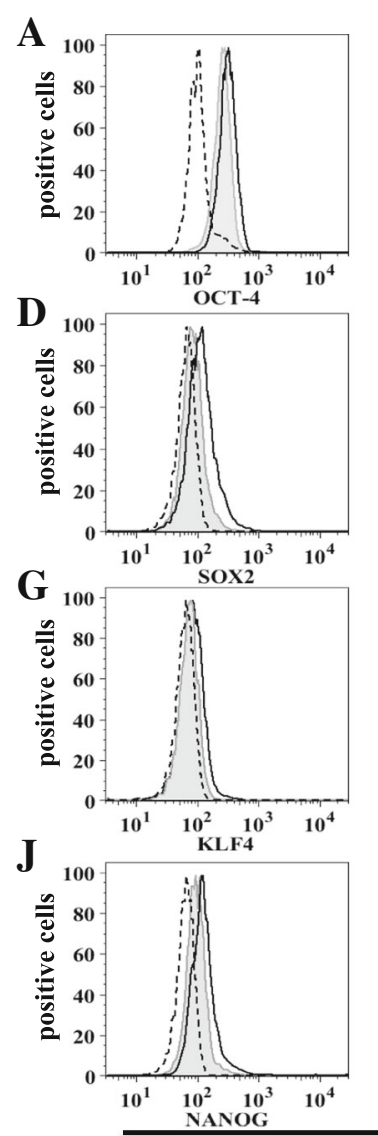
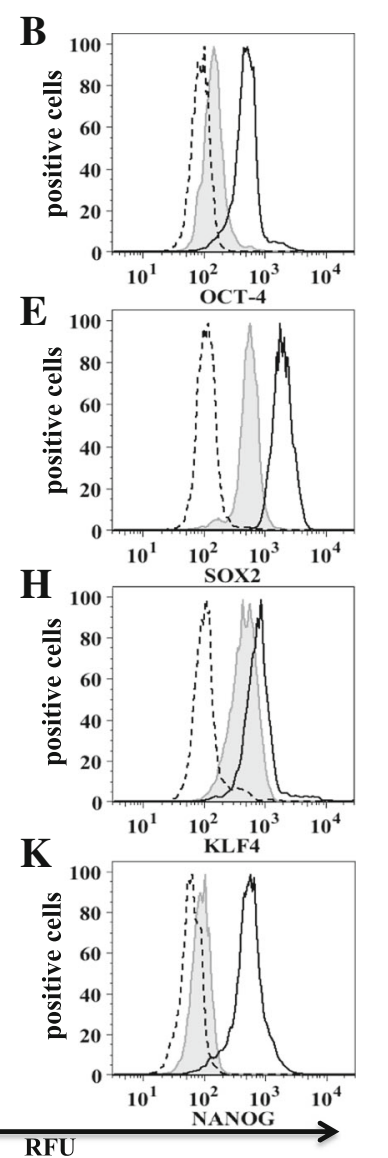

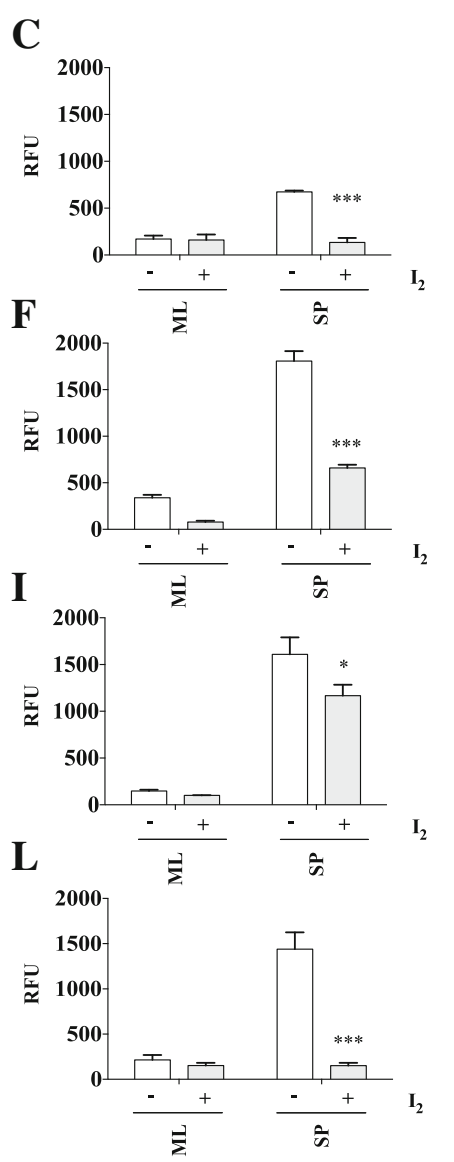

C

Fig. $5 I_{2}$ treatment significantly reduces OCT-4, SOX2, KLF4 and NANOG in SiHa cells grown as spheres. Monolayer cultures of SiHa cells were treated with $200 \mu \mathrm{M}\left(\mathrm{I}_{2}\right)$ for $24 \mathrm{~h}$ (tinted with line), without treatment (black line), isotype (long dashes) (a, $\mathbf{d}, \mathbf{g}$, j). Sphere cultures of SiHa cells were treated with $200 \mu \mathrm{M}\left(\mathrm{I}_{2}\right)$ for $24 \mathrm{~h}$ (tinted with line), without treatment (black line), isotype (long dashes) (b, e, $\left.\mathbf{h}, \mathbf{k}\right)$. Markers were analyzed by flow cytometry $(\mathbf{a}, \mathbf{b}, \mathbf{d}, \mathbf{e}, \mathbf{g}, \mathbf{h}, \mathbf{j}, \mathbf{k})$. Data are expressed as mean $\pm S D(n=3$ independent assays), and the asterisk indicates a significant difference with respect to the control $\left({ }^{*} P<0.05,{ }^{* *} P<0.001\right)(\mathbf{c}, \mathbf{f}, \mathbf{i}, \mathbf{l})$

cultures have been shown to enrich CSC-like cells and are a good system to evaluate CSC-related characteristics of solid tumors in vitro [37], but according to Blagosklonny (reviewed in [38]), these cells should be called stemloids since they possess high proliferation capacity, self-renewal and could be responsible for the reappearance of cancer after therapy. Many studies evaluate the biology of CSC and the mechanisms that give them chemo-resistance capacity. CSC shows resistance to many chemotherapeutics such as cisplatin, 5-FU, and doxorubicin. This is achieved through their high expression of pro-survival proteins, efficient $A B C$ transporters to pump out drugs, signaling pathways that give them resistance properties, and much higher activated phosphorylation of DNA damage response factors [39-42]. Several strategies have been used to inhibit all these properties but they have not been enough, so the chemo-resistance of CSC requires new approaches aimed at eliminating these highly tumorigenic cells.

Molecular iodine has been studied in several cancer cell lines showing its ability to inhibit proliferation, chemo-resistance, and apoptotic effects [30-35], however there are no reports on its effect on cervical cancer cell lines nor on cultures enriched with cancer stem-like cells. $\mathrm{HeLa}$ and $\mathrm{SiHa}$ are the most representative cervical cancer cell lines and in this study, we used cultures grown under non adherent conditions (cervospheres) where we obtained a higher proportion of CSCC-like cells compared to traditional monolayer cultures, allowing us to study the effect of $\mathrm{I}_{2}$ on CSC derived from cervical cancer cell lines. We showed that $\mathrm{I}_{2}$ treatment decreased cervosphere formation, additionally, we observed living cells and some dead cells in these spheres; however, we do not know whether $\mathrm{I}_{2}$ treatment induces death in CCSC-like cells. Our group, as well as other authors, has proposed CD49f and CK17 as putative markers to isolate cervical cancer stem cells $[15,16]$. CD49f is considered to be a stem cell marker for normal and cancer cells and is the only marker that is shared by more than 30 stem cell populations, being one of its main characteristics the maintenance of self-renewal (reviewed in [43]). It's also a crucial 

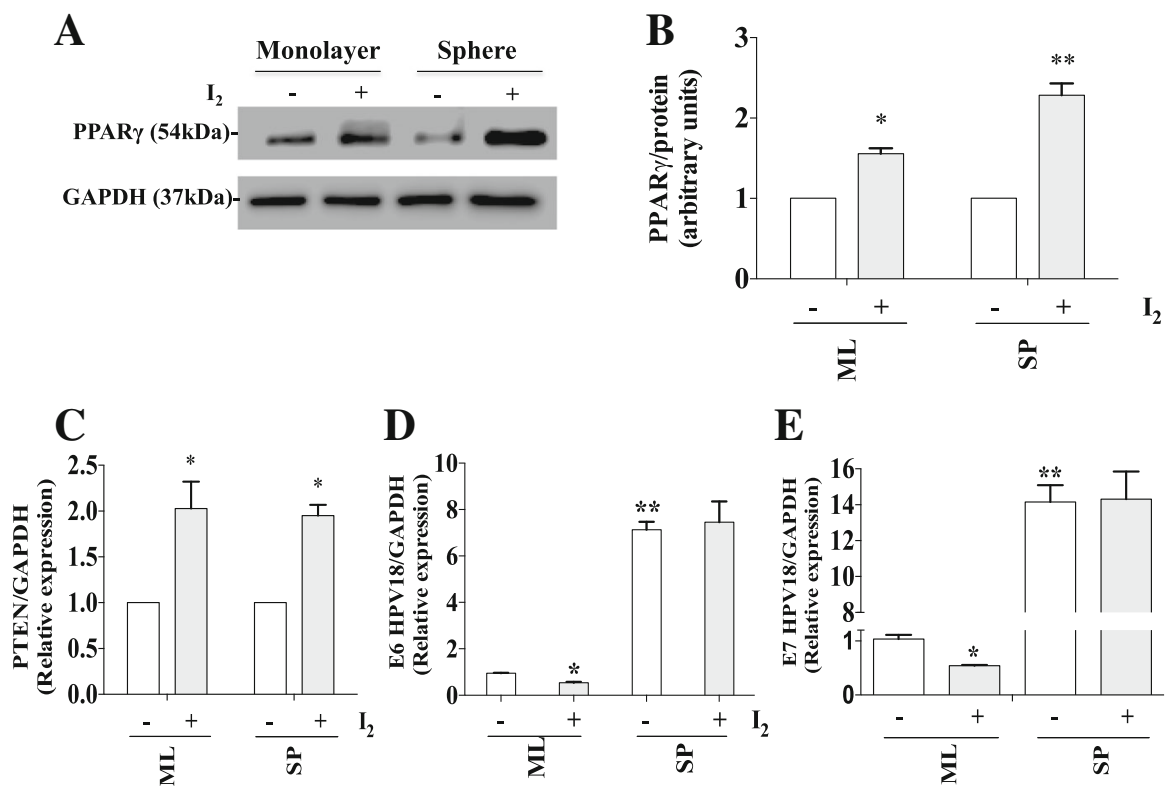

D

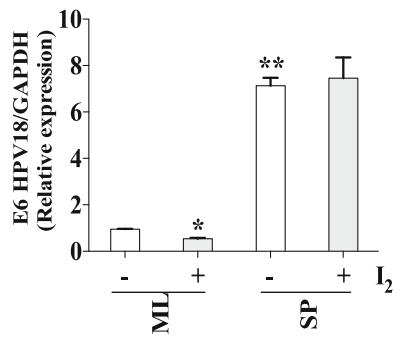

$\mathbf{E}$

Fig. 6 PPARyand PTEN are increased in HeLa cells with $I_{2}$ treatment. Monolayer and sphere cultures of HeLa cells were treated with $200 \mu M\left(I_{2}\right)$ for $24 \mathrm{~h}$ and PPARY protein was quantified by Western blot and densitometry is reported as percent change with respect to control without treatment. (a, b). PTEN expression was analyzed by qPCR and normalized to GAPDH expression (c). HPV18 E6 and E7 oncoproteins expression were analyzed by qPCR and normalized to GAPDH expression (d, e). Data are expressed as mean \pm SD $(n=3$ independent assays), and the asterisk indicates a significant difference with respect to the control without treatment. $\left({ }^{*} P<0.05,{ }^{*} P<0.01\right)$

molecule for the growth and survival of the breast stem cell-like subpopulation that displays increased proliferation and greater resistance to pro-apoptotic agents [44]. The importance of CD49f in cervical cancer is enhanced by its ability to act as a co-receptor for the entry of HPV into the host cells $[45,46]$. CK17 is a marker of the HPV target cell, the cervical reserve (stem) cell which gives rise to metaplasia, and loss of CK17 induces cellular differentiation and attenuates tumorigenesis in cervical epithelia $[21,22,47,48]$. We observed that cells treated with $\mathrm{I}_{2}$ show a decrease in CD49f and CK17 protein expression, molecules considered to be CCSC phenotype markers (reviewed in $[43,49]$ ). Since CD49f is important for maintaining stem cell self-renewal, we hypothesize that the decrease in CD49f + cells caused by $\mathrm{I}_{2}$ could have an important effect on the CCSC-like biology, including tumorigenic capability. To validate the tumorigenic capability of a human cancer cell line, xenotransplantation must be performed in immunodeficient mice, a model used to promote tumor growth derived from human cancer for the analysis of malignant tumors and the evaluation of antitumor drugs [50]. Since $\mathrm{I}_{2}$ exhibited similar effects on HeLa and $\mathrm{SiHa}$ cell lines, we decided to use only HeLa cells for in vivo experiments to evaluate its effect over CCSC. Mice assays, using $\mathrm{I}_{2}$-treated cells, we observed that $\mathrm{I}_{2}$ treatment delays tumor growth, and make them unable to keep the tumor growing, suggesting that $\mathrm{I}_{2}$-treated CCSC-like cells have a lower capacity for tumor formation compared to non-treated CCSC-like cells. However, since the cells are still alive after $I_{2}$ treatment, it's clear that $I_{2}$ treatment can help reduce their tumorigenic capability as observed through the reduction of tumor size and delayed tumor growth. Evaluation of HeLa monolayer cells treated with $\mathrm{I}_{2}$ were not pursued, since we focused our interests in evaluating the effect of $\mathrm{I}_{2}$ in cancer stem-like cells. Additionally, the effect of $\mathrm{I}_{2}$ on CCSC-like cells was observed by evaluating stemness markers, such as NANOG, SOX2, KLF4 and OCT-4, in cervospheres. It has been demonstrated that there is an increase in expression of these stemness markers in cervical carcinomas, compared with normal cervical tissue, and that their overexpression in cell lines derived from cervical cancer confers them an increased capacity for proliferation, clonogenicity, and tumorigenicity in vitro and in vivo, as well as promoting stem cell characteristics [51-54]. Interestingly, we observed different stemness marker levels between HeLa and $\mathrm{SiHa}$ cervospheres, mainly in KLF4 and SOX2 protein levels. This indicates that the mechanisms for self-renewal could be cell type-dependent. Our cervospheres showed overexpression of these stemness markers compared with their monolayer counterparts, as reported [15, 16]. Furthermore, $\mathrm{I}_{2}$ had the ability to decrease their expression in cervospheres, supporting a role for $I_{2}$ in decreasing the tumorigenic capacity of these cancer cells, because as reported in the literature, the decrease of these stem cell markers makes the cancer cells less tumorigenic 


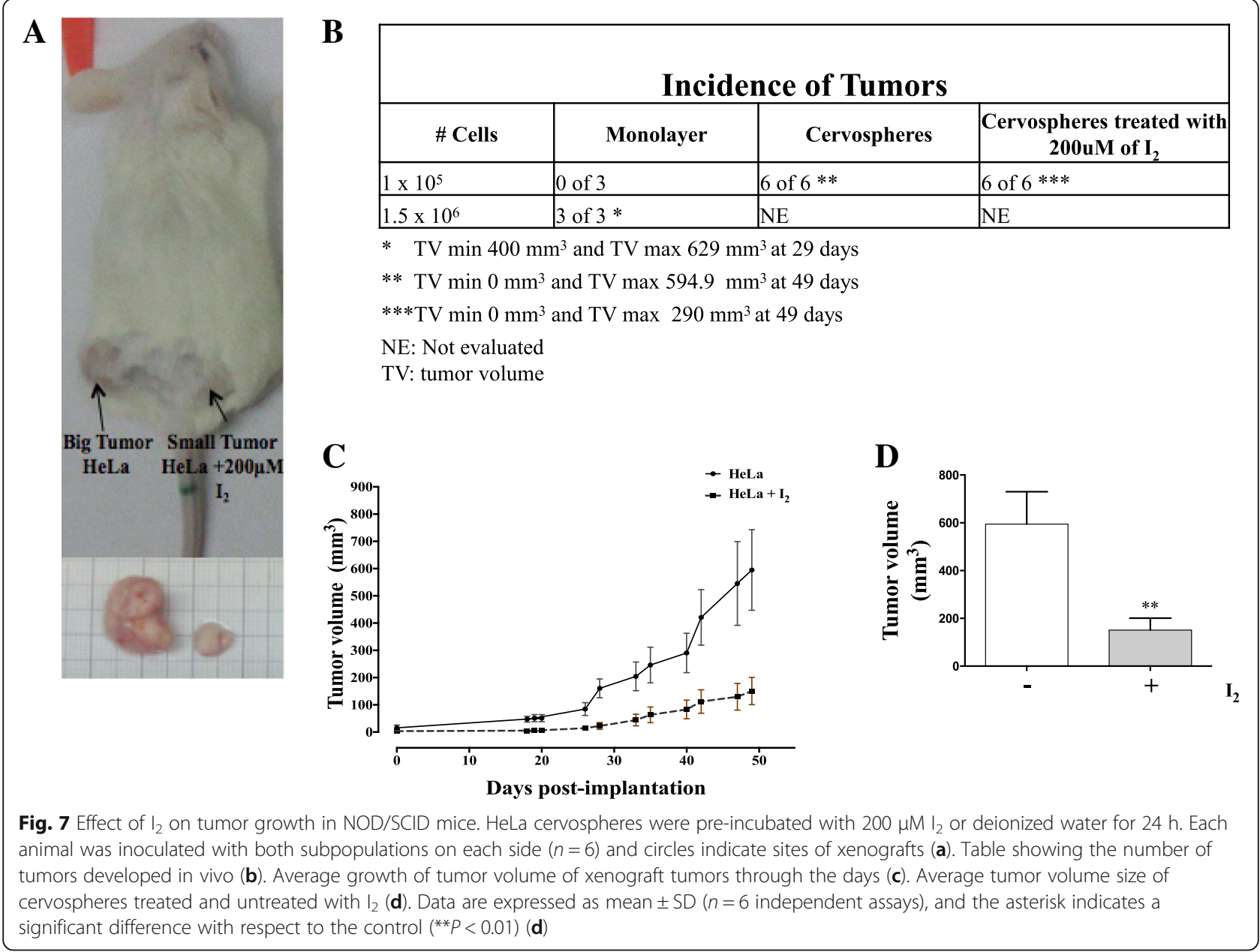

$[27-29,54]$. The mechanism proposed by which $I_{2}$ decreases cell proliferation is through the interaction and activation of the PPAR gamma receptor [34, 55]. In this work we show that in CCSC-like cells derived from $\mathrm{I}_{2}$-treated cervical cancer cell lines, PPAR gamma protein level was increased compared to untreated CCSC-like cells. As consequence, PPAR gamma activation promotes greater expression of its target gene, PTEN [56], in our CCSC-like cultures compared to their monolayer counterparts. These observations suggest that the mechanism whereby $\mathrm{I}_{2}$ decreases CD49f, CK17 and stemness markers in CCSC-like cells could be mediated by the activation of PPAR gamma receptors and consequently the activation of its PTEN response gene involved in self-renewal mechanisms. In addition to decreasing self-renewal capacity, PTEN activation reduces cell proliferation and tumorigenicity in CSC (reviewed in [57]). However, additional assays are needed to further address the mechanism by which $\mathrm{I}_{2}$ is able to decrease the tumor volume derived from CCSC-like cells.

Tyagi and collaborators demonstrated that the increase of E6 and E7 gene expression is close related with the stemness mediated by HES1, a specific transcription factor of NOTCH signal pathway [58]. In our conditions, we also observed an increase of E6/E7 expression in spheres cultures. Interesting, $\mathrm{I}_{2}$ treatment decrease the E6/E7 expression in HeLa monolayer cell culture conditions, an effect that was no observed in sphere culture conditions, suggesting that $\mathrm{I}_{2}$ doesn't have any effect on E6/E7 HPV18 gene expression in CCSC-like.

\section{Conclusions}

In resume, our results demonstrate the $I_{2}$-mediated cytotoxic effect in CSC derived from cervical cancer cell lines, in which CD49f, CK17 and stemness marker positive cells are decreased. Since $\mathrm{I}_{2}$ supplements are considered to be safe for the treatment of diseases such as human mammary fibrocystic disease, breast cancer or prostate hyperplasia (reviewed in [30]), we suggest that $\mathrm{I}_{2}$ treatment for cancer should be studied in preclinical trials to evaluate its potential anti-cancer effect alone or in a combination with conventional therapeutic drugs, to eliminate cancer stem cells from cervical cancer and others. 


\section{Abbreviations}

6-IL: 6-iodolactone; CCSC: Cervical cancer stem cells; CSC: Cancer stem cells; ES: Embryonic stem; HPV: Human papillomaviruses; $\mathrm{I}_{2}$ : Molecular lodine; PPARY: Peroxisome proliferator-activated receptor type gamma; PTEN: Phosphatase and tensin homolog deleted on chromosome ten

\section{Acknowledgments}

We thank the LABNALCIT-UNAM (CONACYT) for the technical support in the acquisition of flow cytometry samples, Programa de Apoyo de Estudios de Posgrado-Universidad Nacional Autónoma de México for grant support to GDB-O, Miriam Guido for technical assistance, Iván Velasco, Ph.D, for critical and academic support, Cody Howe, Joseph Bires for proofreading and Elizabeth Langley McCarron, Ph.D, for proofreading and critical discussion. This manuscript is part of the doctoral dissertation project of Gabriele Davide Bigoni-Ordóñez, a student of the Programa de Maestría y Doctorado en Ciencias Bioquímicas, Universidad Nacional Autónoma de México (UNAM), Ciudad de México, México.

\section{Funding}

This work was supported by Consejo Nacional de Ciencia y Tecnología (CONACYT-México grant 0253804 to AG-C) and Instituto Nacional de Cancerología (INCan to AG-C), Secretaría de Salud (México). The funding bodies had no role in the design of the study, collection, analysis, interpretation of data and, in writing the manuscript. Funding was for purchase of chemicals and kits required for conducting the study. CONACYT-México grant (4141259) and SENESCYT (Ecuador), were fellowships to support the doctoral studies of Gabriele Davide Bigoni-Ordóñez.

\section{Availability of data and materials}

The data analyzed during this study are included in this published article.

\section{Authors' contributions}

GDB-O performed all the experiments, participated in scientific discussions and wrote the manuscript; EO-S performed flow cytometry assays and participated in scientific discussions; PR-C performed RT-qPCR assays; HAV-G performed in vivo tumorigenic assays; CA and AG-C provided the concept design and scientific direction, led scientific discussions and contributed to editing and drafting of the manuscript. All authors have read and approved the final manuscript.

\section{Ethics approval}

The Committee for Research Ethics and for Animal Care and Use in Research, Instituto Nacional de Cancerología, Mexico City (Mexico) approved the present study [Prot. No. 018/012//BI) (CEI/1096/17)]. We handled animals in compliance with the revised Animals (Scientific Procedures) Act 1986. This article adheres to the ARRIVE guidelines (https://www.nc3rs.org.uk/arrive-guidelines) for the reporting of animal experiments.

\section{Consent for publication}

Not applicable.

\section{Competing interests}

The authors declare that they have no competing interests.

\section{Publisher's Note}

Springer Nature remains neutral with regard to jurisdictional claims in published maps and institutional affiliations.

\footnotetext{
Author details

${ }^{1}$ División de Investigación Básica, Laboratory of Virus and Cancer, Instituto Nacional de Cancerología, Secretaria de Salud, Av. San Fernando No. 22, Sección XVI, Tlalpan, 14080 Ciudad de México, CP, Mexico. ${ }^{2}$ Programa de Maestría y Doctorado en Ciencias Bioquímicas, Facultad de Química, UNAM, Mexico City, Mexico. ${ }^{3}$ Programa de Doctorado en Ciencias Biomédicas, UNAM, Mexico City, Mexico. ${ }^{4}$ Instituto de Neurobiología, Universidad Nacional Autónoma de México, Boulevard Juriquilla 3001, Juriquilla. Campus-Juriquilla., Querétaro 76230, Qro, Mexico. ${ }^{5}$ Instituto de Investigaciones Biomédicas, Universidad Naciona Autónoma de México, Mexico City, Mexico.
}

Received: 8 March 2018 Accepted: 14 September 2018

Published online: 26 September 2018

\section{References}

1. Ferlay J, Soerjomataram I, Dikshit R, Eser S, Mathers C, Rebelo M, Parkin DM, Forman D, Bray F. Cancer incidence and mortality worldwide: sources, methods and major patterns in GLOBOCAN 2012. Int J Cancer. 2015;136(5): E359-86.

2. zur Hausen H. Papillomaviruses and cancer: from basic studies to clinical application. Nat Rev Cancer. 2002;2(5):342-50.

3. Boulet G, Horvath C, Broeck VD, Sahebali S, Bogers J. Human papillomavirus: E6 and E7 oncogenes. Int J Biochem Cell Biol. 2007;39(11):2006-11.

4. Ueno T, Sasaki K, Yoshida S, Kajitani N, Satsuka A, Nakamura H, Sakai H. Molecular mechanisms of hyperplasia induction by human papillomavirus E7. Oncogene. 2006:25(30):4155-64.

5. O'Brien CA, Kreso A, Dick JE. Cancer stem cells in solid tumors: an overview. Semin Radiat Oncol. 2009;19(2):71-7.

6. Reya T, Morrison SJ, Clarke MF, Weissman IL. Stem cells, cancer, and cancer stem cells. Nature. 2001;414:105-11.

7. Aulmann S, Waldburger N, Penzel R, Andrulis M, Schirmacher P, Sinn HP. Reduction of CD44(+)/CD24(-) breast cancer cells by conventional cytotoxic chemo- therapy. Hum Pathol. 2010;41(4):574-81.

8. Vermeulen L, de Sousa e Melo F, Richel DJ, Medema JP. The developing cancer stem-cell model: clinical challenges and opportunities. The Lancet Oncol. 2012;13(2):e83-9.

9. Lee HE, Kim JH, Kim YJ, Choi SY, Kim SW, Kang E, Chung IY, Kim IA, Kim EJ Choi Y, Ryu HS, Park SY. An increase in cancer stem cell population after primary systemic therapy is a poor prognostic factor in breast cancer. $\mathrm{Br}$ J Cancer. 2011:104:1730-8.

10. Al-Hajj M, Wicha MS, Benito-Hernandez A, Morrison SJ, Clarke MF. Prospective identification of tumorigenic breast cancer cells. Proc Natl Acad Sci U S A. 2003;100(7):3983-8.

11. O'Brien CA, Pollett A, Gallinger S, Dick JE. A human colon cancer cell capable of initiating tumour growth in immunodeficient mice. Nature. 2007; 445(7123):106-10

12. Singh SK, Clarke ID, Terasaki M, Bonn VE, Hawkins C, Squire J, Dirks PB. Identification of a cancer stem cell in human brain tumors. Cancer Res. 2003;63(18):5821-8.

13. Dick JE. Acute myeloid leukemia stem cells. Ann N Y Acad Sci. 2005;1044:1-5.

14. Hardavella G, George R, Sethi T. Lung cancer stem cells-characteristics, phenotype. Transl Lung Cancer Res. 2016;5(3):272-9.

15. López J, Poitevin A, Mendoza-Martínez V, Pérez-Plasencia C, García-Carrancá A. Cancer-initiating cells derived from established cervical cell lines exhibit stem-cell markers and increased radioresistance. BMC Cancer. 2012:12:48.

16. Ortiz-Sánchez E, Santiago-López L, Cruz-Domínguez VB, Toledo-Guzmán ME, Hernández-Cueto D, Muñiz-Hernández S, Garrido E, Cantú De León D, García-Carrancá A. Characterization of cervical cancer stem cell-like cells: phenotyping, stemness, and human papilloma virus co-receptor expression. Oncotarget. 2016;7(22):31943-54

17. Webb A, Li A, Kaur P. Location and phenotype of human adult keratinocyte stem cells of the skin. Differentiation. 2004;72(8):387-95.

18. Haraguchi N, Ishii H, Mimori K, Ohta K, Uemura M, Nishimura J, Hata T, Takemasa I, Mizushima T, Yamamoto H, Doki Y, Mori M. CD49f-positive cell population efficiently enriches colon cancer-initiating cells. Int J Oncol. 2013, 43(2):425-30.

19. Raff AB, Woodham AW, Raff LM, Skeate JG, Yan L, Da Silva DM, Schelhaas M, Kast WM. The evolving field of human papillomavirus receptor research: a review of binding and entry. J Virol. 2013;87(11):6062-72.

20. Smedts F, Ramaekers F, Troyanovsky S, Pruszczynski M, Robben H, Lane B, Leigh I, Plantema F, Vooijs P. Basal-cell keratins in cervical reserve cells and a comparison to their expression in cervical intraepithelial neoplasia. Am J Pathol. 1992;140(3):601-12.

21. Martens JE, Arends J, Van der Linden PJ, De Boer BA, Helmerhorst TJ. Cytokeratin 17 and p63 are markers of the HPV target cell, the cervical stem cell. Anticancer Res 2004;24(2B):771-775.

22. Feng D, Peng C, Li C, Zhou Y, Li M, Ling B, Wei H, Tian Z. Identification and characterization of cancer stem-like cells from primary carcinoma of the cervix uteri. Oncol Rep. 2009;22(5):1129-34.

23. Rosner MH, Vigano MA, Ozato K, Timmons PM, Poirie F, Rigby PWJ, Staudt LM. A pou-domain transcription factor in early stem cells and germ cells of the mammalian embryo. Nature. 1990;345(6277):686-92. 
24. Pereira L, Yi F, Merrill BJ. Repression of nanog gene transcription by Tcf3 limits embryonic stem cell self-renewal. Mol Cell Biol. 2006;26(20):7479-91.

25. Sarkar A, Hochedlinger $K$. The sox family of transcription factors: versatile regulators of stem and progenitor cell fate. Cell Stem Cell. 2013;12(1):15-30.

26. Li Y, McClintick J, Zhong L, Edenberg HJ, Yoder MC, Chan RJ. Murine embryonic stem cell differentiation is promoted by SOCS-3 and inhibited by the zinc finger transcription factor Klf4. Blood. 2005;105(2):635-7.

27. Ben-Porath I, Thomson MW, Carey VJ, et al. An embryonic stem cell-like gene expression signature in poorly differentiated aggressive human tumors. Nat Genet. 2008;40(5):499-507.

28. Tai SK, Yang MH, Chang SY, Chang YC, Li WY, Tsai TL, Wang YF, Chu PY, Hsieh SL. Persistent Kruppel-like factor 4 expression predicts progression and poor prognosis of head and neck squamous cell carcinoma. Cancer Sci. 2011;102(4):895-902

29. Wang Y-D, Cai N, Wu XL, Cao HZ, Xie LL, Zheng PS. OCT4 promotes tumorigenesis and inhibits apoptosis of cervical cancer cells by miR-125b/ BAK1 pathway. Cell Death Dis. 2013:4:e760.

30. Rosner H, Torremante P, Moller W, Gartner R. Antiproliferative/cytotoxic activity of molecular iodine and iodolactones in various human carcinoma cell lines. No interfering with EGF-signaling, but evidence for apoptosis. Exp Clin Endocrinol Diabetes. 2009:118(7):410-9.

31. Vitale M, Di Matola T, D'Ascoli F, Salzano S, Bogazzi F, Fenzi G, Martino E, Rossi G. lodide excess induces apoptosis in thyroid cells through a p53independent mechanism involving oxidative stress. Endocrinology. 2000; 141(2):598-605

32. Arroyo-Helguera O, Rojas E, Delgado G, Aceves C. Signaling pathways involved in the antiproliferative effect of molecular iodine in normal and tumoral breast cells: evidence that 6-iodolactone mediates apoptotic effects. Endocr Relat Cancer. 2008;15(4):1003-11.

33. Nuñez-Anita RE, Arroyo-Helguera O, Cajero-Juárez M, López-Bojorquez L, Aceves C. A complex between 6-iodolactone and the peroxisome proliferator-activated receptor type gamma may mediate the antineoplastic effect of iodine in mammary cancer. Prostaglandins Other Lipid Mediat. 2009:89(1-2):34-42.

34. Nava-Villalba M, Aceves C. 6-iodolactone, key mediator of antitumoral properties of iodine. Prostaglandins Other Lipid Mediat. 2014;112:27-33.

35. Bontempo A, Ugalde-Villanueva B, Delgado-González E, Rodríguez ÁL, Aceves C. Molecular iodine impairs chemoresistance mechanisms, enhances doxorubicin retention and induces downregulation of the CD44+/CD24+ and E-cadherin+/vimentin+ subpopulations in MCF-7 cells resistant to low doses of doxorubicin. Oncol Rep. 2017;38(5):2867-76

36. Teresi RE, Waite KA. PPARgamma, PTEN, and the fight against Cancer. PPAR Res. 2008;2008:932632

37. Ishiguro T, Ohata H, Sato A, Yamawaki K, Enomoto T, Okamoto K. Tumorderived spheroids: relevance to cancer stem cells and clinical applications. Cancer Sci. 2017;108(3):283-9.

38. Blagosklonny MV. Cancer stem cell and cancer stemloids: from biology to therapy. Cancer Biol Ther. 2007;6:1684-90

39. Noda T, Nagano H, Takemasa I, Yoshioka S, Murakami M, Wada H, Kobayashi S, Marubashi S, Takeda Y, Dono K, et al. Activation of Wnt/beta-catenin signalling pathway induces chemoresistance to interferon-alpha/5fluorouracil combination therapy for hepatocellular carcinoma. Br J Cancer. 2009:100:1647-58.

40. Flahaut M, Meier R, Coulon A, Nardou KA, Niggli FK, Martinet D, Beckmann JS, Joseph JM, Muhlethaler-Mottet A, Gross N. The Wnt receptor FZD1 mediates chemoresistance in neuroblastoma through activation of the Wnt/ beta-catenin pathway. Oncogene. 2009;28:2245-56.

41. Gallmeier E, Hermann PC, Mueller MT, Machado JG, Ziesch A, De Toni EN, Palagyi A, Eisen C, Ellwart JW, Rivera J, et al. Inhibition of ataxia telangiectasia- and Rad3-related function abrogates the in vitro and in vivo tumorigenicity of human colon cancer cells through depletion of the CD133(+) tumor-initiating cell fraction. Stem Cells. 2011;29:418-429.36.

42. Madjd Z, Mehrjerdi AZ, Sharifi AM, Molanaei S, Shahzadi SZ, Asadi-Lari M CD44+ cancer cells express higher levels of the anti-apoptotic protein Bcl-2 in breast tumours. Cancer Immun. 2009;9:4.

43. Krebsbach PH, Villa-Diaz LG. The role of integrin in stem cells: more than a conserved biomarker. Stem Cells Dev. 2017;26(15):1090-9.

44. Cariati M, Naderi A, Brown JP, Smalley MJ, Pinder SE, Caldas C, Purushotham AD. Alpha-6 integrin is necessary for the tumourigenicity of a stem cell-like subpopulation within the MCF7 breast cancer cell line. Int J Cancer. 2008; 122(2):298-304.

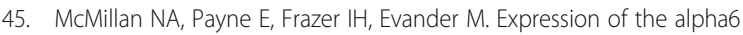
integrin confers papillomavirus binding upon receptor-negative B-cells. Virology. 1999;261(2):271-9.

46. Evander M, Frazer IH, Payne E, Qi YM, Hengst K, Mc Millan NA. Identification of the alpha6 integrin as a candidate receptor for papillomaviruses. J Virol. 1997;71(3):2449-56.

47. Regauer S, Reich O. CK17 and p16 expression patterns distinguish (atypical) immature squamous metaplasia from high- grade cervical intraepithelial neoplasia (CIN III). Histopathology. 2007;50(5):629-35.

48. Hobbs RP, Batazzi AS, Han MC, Coulombe PA. Loss of keratin 17 induces tissue-specific cytokine polarization and cellular differentiation in HPV16driven cervical tumorigenesis in vivo. Oncogene. 2016;35(43):5653-62.

49. Ikeda K, Tate G, Suzuki T, Mitsuya T. Coordinate expression of cytokeratin 8 and cytokeratin 17 immunohistochemical staining in cervical intraepithelial neoplasia and cervical squamous cell carcinoma: an immunohistochemical analysis and review of the literature. Gynecol Oncol. 2008;108(3):598-602.

50. Engel AM, Schou M. Assay of tumorigenicity in nude mice. In: Celis JE, Carter NP, Simons K, Small JV, Hunter T, Shotton DM, editors. Cell biology: a laboratory handbook. Burlington: Eds. Elsevier Academic; 2006. p. 353-7.

51. Liu XF, Yang WT, Xu R, Liu JT, Zheng PS. Cervical cancer cells with positive Sox2 expression exhibit the properties of cancer stem cells. PLoS One. 2014; 9(1):e87092.

52. Li SW, Wu XL, Dong CL, Xie XY, Wu JF, Zhang X. The differential expression of OCT4 isoforms in cervical carcinoma. PLoS One. 2015;10(3):e0118033.

53. Mak VC, Siu MK, Wong OG, Chan KK, Ngan HY, Cheung AN. Dysregulated stemness-related genes in gynecological malignancies. Histol Histopathol. 2012;27(9):1121-30.

54. Ding $Y, Y u A Q$, Wang $X L$, Guo XR, Yuan YH, Li DS. Forced expression of Nanog with mRNA synthesized in vitro to evaluate the malignancy of HeLa cells through acquiring cancer stem cell phenotypes. Oncol Rep. 2016;35(5): 2643-50.

55. Nava-Villalba M, Nuñez-Anita RE, Bontempo A, Aceves C. Activation of peroxisome proliferator-activated receptor gamma is crucial for antitumoral effects of 6-iodolactone. Mol Cancer. 2015;14:168.

56. Teresi RE, Shaiu CW, Chen CS, Chatterjee VK, Waite KA, Eng C. Increased PTEN expression due to transcriptional activation of PPARgamma by lovastatin and rosiglitazone. Int J Cancer. 2006;118(10):2390-8.

57. Ciuffreda L, Falcone I, Incani UC, Del Curatolo A, Conciatori F, Matteoni S, Vari S, Vaccaro V, Cognetti F, Milella M. PTEN expression and function in adult cancer stem cells and prospects for therapeutic targeting. Adv Biol Regul. 2014;56:66-80.

58. Tyagi A, Vishnoi K, Mahata S, Verma G, Srivastava Y, Masaldan S, Roy BG, Bharti AC, Das BC. Cervical Cancer stem cells selectively overexpress HPV Oncoprotein E6 that controls Stemness and self-renewal through upregulation of HES1. Clin Cancer Res. 2016;22(16):4170-84.

Ready to submit your research? Choose BMC and benefit from:

- fast, convenient online submission

- thorough peer review by experienced researchers in your field

- rapid publication on acceptance

- support for research data, including large and complex data types

- gold Open Access which fosters wider collaboration and increased citations

- maximum visibility for your research: over $100 \mathrm{M}$ website views per year

At BMC, research is always in progress.

Learn more biomedcentral.com/submissions 